\title{
Inter- and intra-rater reliability of computerized photogrammetry and universal goniometer in the measurement of hip flexion and abduction
}

Confiabilidade inter e intra-avaliadores na fotogrametria e do goniometro universal na medida da abdução e flexão do quadril

La exactitud inter y intraexaminadores de la fotogrametría y del goniómetro universal en mediciones de abducción y flexión de las caderas

\section{Amélia Pasqual Marques', Juliana Naomi Oshima Marcolan², Juliana Nucci Nogueira Prado², Thomaz Nogueira Burke ${ }^{3}$, Elizabeth Alves Gonçalves Ferreira' ${ }^{1}$}

\begin{abstract}
The universal goniometer (UG) is the most frequently used tool for measuring range of motion (ROM), with demonstrated reliability. Computerized photogrammetry (CP) is widely used for postural assessment, but its role in the measurement of ROM of hip flexion and abduction has not yet been fully explored. This study aimed to test inter- and intra-rater reliability for measuring ROM of hip flexion and abduction using UG and $\mathrm{CP}$, as well as the reliability between the instruments. Our sample consisted of 40 healthy volunteers (aged from 18 to 28 years). Measurements of ROM were conducted by two independent raters, 15 minutes apart, using UG and $\mathrm{CP}$ to assess inter-rater reliability. The procedures were repeated one week later by the first rater (intra-rater reliability). Using $\cup G$, inter-rater reliability was excellent for flexion and abduction (ICC=0.92 and 0.91, respectively); using CP, it was rated as very good (ICC=0.77 and 0.80, respectively). Intra-rater reliability using $U G$ was excellent for flexion and abduction (ICC=0.95 and 0.92), and very good using $\mathrm{CP}(\mathrm{ICC}=0.81$ and 0.89$)$. The correlation between the instruments was excellent for flexion and very good for abduction ( $r=0.92$ and $r=0.82)$. Future investigations should seek a more diversified sample and symptomatic patients. Inter- and intra-rater reliability is high when measuring range of motion of hip flexion and abduction using both UG and CP, and the correlation between instruments is excellent for flexion and very good for abduction, meaning that both are valid.
\end{abstract}

Keywords | Data Accuracy; Physical Therapy Modalities.

RESUMO I O goniômetro universal (GU) é uma ferramenta, com credibilidade comprovada, mais frequentemente usada para medir a amplitude de movimento (AM). A fotogrametria computadorizada (FC) é amplamente utilizada para avaliação postural, mas seu uso para medir a AM da abdução e flexão do quadril ainda não foi totalmente explorado. Este estudo visou testar a confiabilidade inter e intra-avaliadores para a medição da AM da abdução e flexão do quadril usando o GU e a FC, além da confiabilidade entre instrumentos. Nossa amostra constituiu-se de 40 voluntários saudáveis (idade entre 18 e 28 anos). As medições da AM foram conduzidas por dois avaliadores independentes, com 15 minutos de intervalo, usando o GU e a FC para analisar a confiabilidade entre avaliadores. Os procedimentos foram repetidos uma semana depois pelo primeiro avaliador (inter e intra-avaliadores). Com o GU, a confiabilidade inter e intra-avaliadores foi excelente para a flexão e abdução (ICC=0,92 e 0,91, respectivamente); a FC foi classificada como muito boa (ICC=0,77 e 0,80, respectivamente). Usando-se o GU, a confiabilidade inter e intra-avaliadores foi excelente para a flexão e abdução (ICC=0,95 e 0,92), e muito boa para a FC (ICC=0,81 e 0,89). A correlação entre instrumentos foi excelente para a flexão e muito boa para a abdução ( $r=0,92$ e $r=0,82)$. Estudos futuros sobre o assunto deveriam usar uma amostra mais diversificada e

'PhD, Professor of the Department of Physical Therapy, Speech Therapy and Occupational Therapy, School of Medicine, Universidade de São Paulo (USP) - São Paulo (SP), Brazil.

${ }^{2}$ Physical Therapist, Department of Physical Therapy, Speech Therapy and Occupational Therapy, School of Medicine, Universidade de São Paulo (USP) - São Paulo (SP), Brazil.

${ }^{3}$ PhD, Physical Therapist, Department of Physical Therapy, Speech Therapy and Occupational Therapy, School of Medicine,

Universidade de São Paulo (USP) - São Paulo (SP), Brazil.

Corresponding address: Amélia Pasqual Marques - Departamento de Fonoaudiologia, Fisioterapia e Terapia Ocupacional (FOFITO), USP - R. Cipotânea, 51, Cidade Universitária São Paulo (SP), Brazil - Zip Code: 05360-000 - E-mail: pasqual@usp.br - Financing source: FAPESP (Fundação de Amparo à Pesquisa do Estado de São Paulo) - Financial disclosure: we certify that no party having a direct interest in the results of the research supporting this article has or will confer a benefit on us or any organization with which we are associated - Conflict of interest: Nothing to declare - Presentation: Nov. 2016 - Accepted for publication: Feb. 2017 - Approved by Comissão de Ética e Pesquisa , $1372 / 09$. 
pacientes sintomáticos. A confiabilidade inter e intra-avaliadores é alta quando se mede a amplitude do movimento da flexão e abdução do quadril, usando-se o GU e a FC, e a correlação entre instrumentos é excelente para a flexão e muito boa para a abdução, o que significa que ambos são válidos.

Descritores | Confiabilidade dos Dados; Modalidades de Fisioterapia.

RESUMEN | El goniómetro universal (GU) es un instrumento comprobadamente fiable que se emplea para medir la amplitud del movimiento (AM). La fotogrametría computadorizada (FC) es más utilizada para evaluar la postura, pero no se emplea mucho para medir la AM de la abducción y flexión de las caderas. En este estudio el propósito es comprobar la exactitud entre e intraexaminadores en medir la AM de la abducción y flexión de las caderas, empleando el GU y la FC, además de la exactitud entre instrumentos. Participaron cuarenta personas sanas (con edad entre 18 y 28 años). Dos examinadores independientes midieron la $\mathrm{AM}$, con 15 minutos de intervalo, empleando el
GU y la FC para evaluar la exactitud entre examinadores. Los procedimientos fueron repetidos una semana después por el primer examinador (entre e intraexaminadores). Con el GU, la exactitud entre e intraexaminadores fue excelente para la flexión y abducción (ICC=0,92 y 0,91, respectivamente); y se clasificó la FC como muy buena (ICC=0,77 y 0,80, respectivamente). Con el empleo del GU, la exactitud intra y entre examinadores fue excelente para la flexión y abducción (ICC=0,95 y 0,92), y muy buena para la $F C$ (ICC=0,81 y 0,89). La correlación entre instrumentos fue excelente para la flexión y muy buena para la abducción ( $r=0,92$ y r=0,82). Se necesitan más estudios que utilicen un muestreo más diverso y con pacientes sintomáticos. La exactitud entra e intraexaminadores es muy eficaz, cuando se mide la amplitud del movimiento de la flexión y abducción de las caderas con el GU y la FC, y la correlación entre instrumentos es excelente para la flexión y muy buena para la abducción, lo que devela que ambos instrumentos son fiables.

Palabras clave | Exactitud de los Datos; Modalidades de Fisioterapia.

\section{INTRODUCTION}

The measurement of articular range of motion (ROM) is a standard component of the assessment of the Musculoskeletal System. It is essential for establishing physiotherapeutic diagnosis, as well as estimating and quantifying the effectiveness of therapeutic intervention, therefore measuring the progress of rehabilitation ${ }^{1-3}$.

Different methods for measuring ROM are available, ranging from visual inspection to the use of precision tools and computer-assisted estimates. Goniometry is often used in clinical practice ${ }^{3,4}$, since universal goniometers (UG) are easy to use, non-invasive, and accessible $^{5}$. Goniometry has established good reliability when compared to radiological assessments, which have been shown to be highly reliable ${ }^{3,6,7}$.

New methodologies for assessing range of motion are important in clinical practice and research. The use of computerized photogrammetry $(\mathrm{CP})$ as quantitative assessment is very important for physical therapy appraisal, and it should be complementary to the qualitative physical therapy analysis increasingly being used in scientific research, allowing the register of small changes in the position of body parts in a way that would be difficult to record using other tools. Therefore, $\mathrm{CP}$ is gaining importance in clinical physical therapy and in research focusing on rehabilitation ${ }^{8-10}$. Another strength of $\mathrm{CP}$ is that measurements are electronically filed, saving physical space and facilitating access to data ${ }^{10}$.

With the aid of specific software, such as postural assessment software (PAS/SAPO) and Corel Draw, CP is now being used in postural assessment ${ }^{11}$. However, little is known about the ability of this tool to measure ROM. Sato et al. ${ }^{12}$ used the method to measure the anterior flexion of the trunk, but the utility of the method for other joints has not yet been assessed ${ }^{12}$.

Accordingly, this study aimed to test inter- and intra-rater reliability for measuring $\mathrm{ROM}$ of hip flexion and abduction using universal goniometer and computerized photogrammetry, as well as the reliability between the instruments.

\section{METHODOLOGY}

Design: Cross-sectional measurement, reliability study. Our sample consisted of 40 healthy subjects of both sexes, aged from 18 to 28 years. Participants were recruited among the students of Physical Therapy at Universidade de São Paulo, Brazil. Inclusion criteria were: active lifestyle according to the short version of the international questionnaire for physical activity ${ }^{13}$ 
and body mass index (BMI) below $24.9 \mathrm{~kg} / \mathrm{cm}^{2}$. Exclusion criteria were: history of injury or trauma to the hip over the past year; disease that may limit ROM of the hip (osteoarthritis, rheumatoid arthritis, congenital dislocation); reported pain in the hip, spine, or knee when performing hip flexion or abduction; fracture of the legs or spine over the past year; or significant scoliosis.

To standardize assessments, only the right hip was assessed. We measured ROM and angles for hip flexion and abduction. Considering that the hip joint has three degrees of freedom, flexion and abduction movements were selected because they occur in the sagittal and frontal planes, that is, in different planes of movement of the joint. The rotational movements occurring in the transverse plane were not evaluated in this study. In this study, we considered 0-125 degrees for flexion and 0-45 degrees for abduction as normal values. Participants were first oriented to conduct each movement three times to minimize the influence of muscular stretching. Measurements were then conducted 15 minutes apart by two different raters. The procedures were repeated one week later by the first rater.

This study was approved by the Ethics Committee of the School of Medicine of Universidade de São Paulo. Participants signed informed consent forms.

\section{GONIOMETRY}

The fixed arm of the GU was placed in the midaxillary line, and the other arm was placed over and in parallel to the lateral surface of the thigh toward the lateral condyles of the femur, with axis near the level of the greater trochanter ${ }^{14}$.

Measurements of passive hip flexion were conducted with participants in supine position. During measurements, arms remained crossed over the chest, with the right knee on flexion while the left knee remained extended. Patients were lying on a stretcher with a height of 76 $\mathrm{cm}$, placed $15 \mathrm{~cm}$ away from the wall; the camera was placed $270 \mathrm{~cm}$ away from the participant and $92 \mathrm{~cm}$ above the floor. Tapes were placed on the right greater trochanter, in the intersection between the last right rib, the midaxillary line, and the lateral femoral condyle. Tape was placed while the participants were in hip flexion to avoid movements due to displacement of soft tissues (Figure 1), and each rater placed the tapes for their measurement.

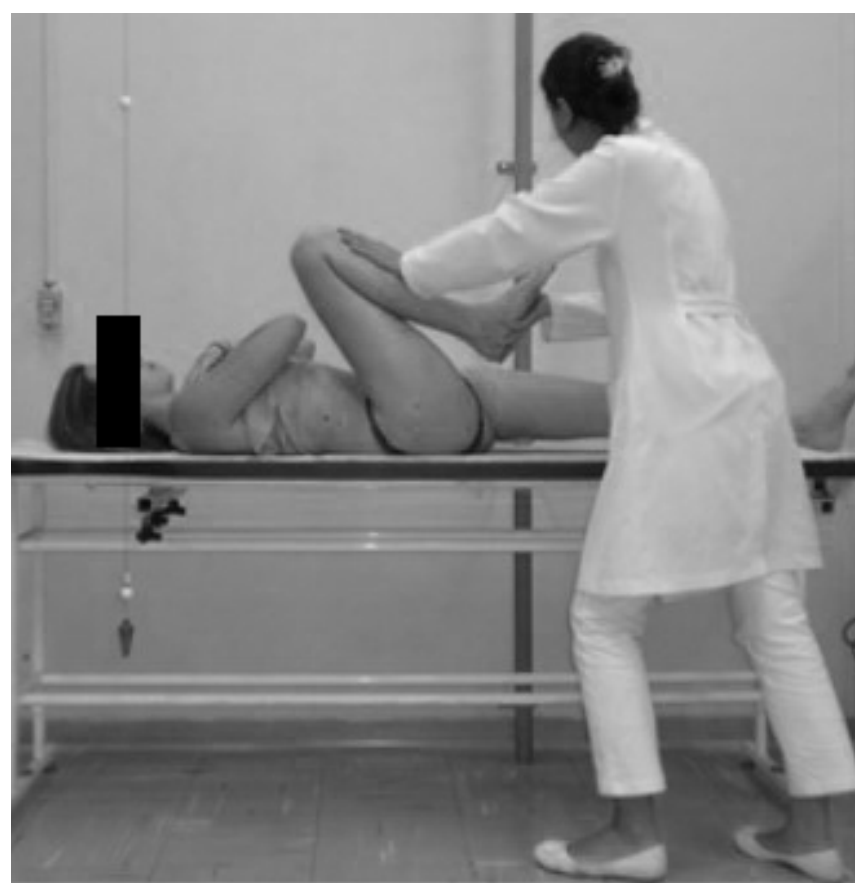

Figure 1. Hip flexion measured by CP

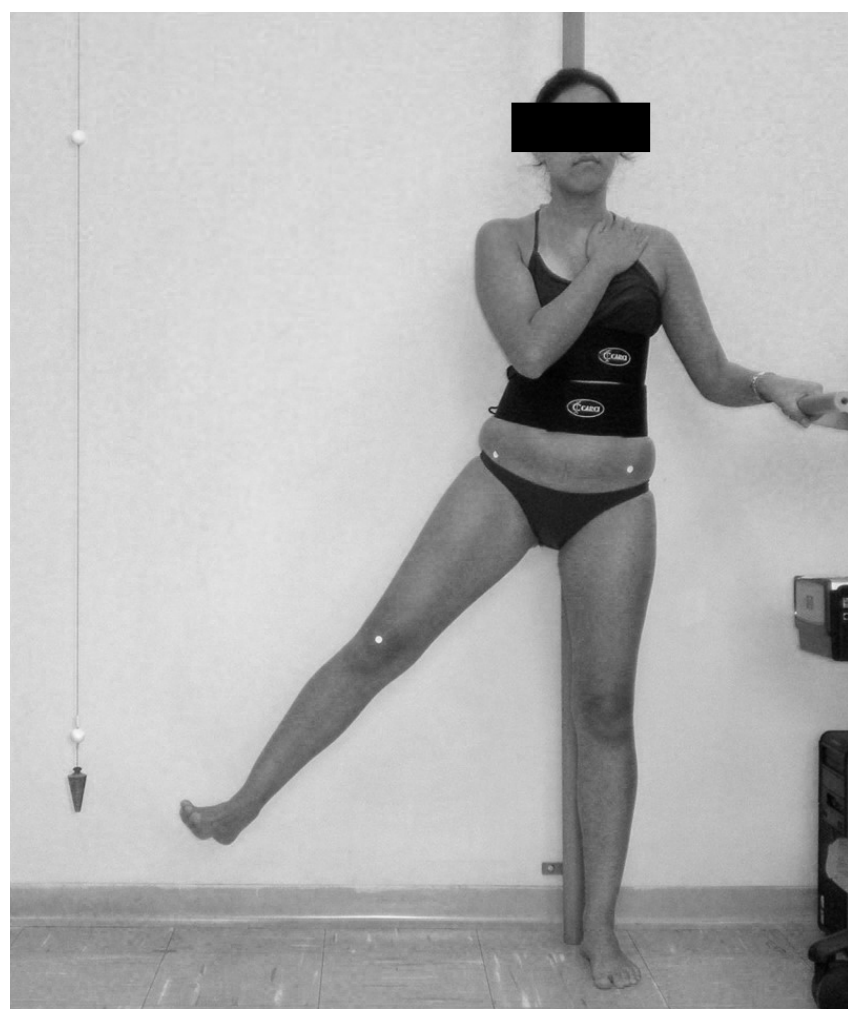

Figure 2. Hip abduction measured by CP

Hip abduction (active) was conducted in standing posterior region of the trunk, and was supported by a sustained system, fixed by bands (one above the breast and a second above the iliac crest). Lateral support was given to the left arm, while the right arm remained over 
the chest. This position was adopted because, in supine position, it was not possible to take the photos. The supporting guide was placed $15 \mathrm{~cm}$ away from the wall and $320 \mathrm{~cm}$ away from the camera. The support for the arm was placed $30 \mathrm{~cm}$ away from the participant and the camera, and $92 \mathrm{~cm}$ above the floor. Double-sided adhesive tapes were placed on the anterior-superior iliac spines and on the center of the right patella (Figure 2).

The fixed arm of the GU was placed on an axis connecting the anterior-superior iliac spines, and the moving arm was aligned to the thigh, along the right femur diaphysis, with the axis over the anteriorsuperior iliac spine ${ }^{14}$. Legs remained in neutral position (without rotation).

\section{PHOTOGRAMMETRY}

Pictures were taken using digital camera (NIKON COOLPIX S220) on a leveled tripod, and were taken in anterior view and right lateral view (Figures 1 and 2). The room was bright, with non-reflexive background, and reserved. References were marked with red adhesive tape (13 $\mathrm{mm}$ diameter). Positional parameters were identical to those described above. Angles were estimated using PAS/SAPO v.0.67 $7^{15}$.

To decrease potential biases, a pilot standardizing study was first conducted, and difficulties were observed, mainly related to the position of participants and to the identification of reference points. To increase the precision of the $\mathrm{CP}$ measures, round red tapes were placed as close as possible to the anatomical structures, and $80 \%$ zoom was standardized on the PAS/SAPO.

For hip flexion, patients were lying on a stretcher with a height of $76 \mathrm{~cm}$, placed $15 \mathrm{~cm}$ away from the wall; the camera was $270 \mathrm{~cm}$ away from the participant and $92 \mathrm{~cm}$ above the floor. Tapes were placed on the right greater trochanter, in the intersection between the last right rib, the midaxillary line, and the lateral femoral condyle. Tape was placed while the participants were in hip flexion to avoid movements due to displacement of soft tissues (Figure 1), and each rater placed the tapes for their measurement.

Normal distribution of data was assessed using the Shapiro-Wilk test. Two-way ANOVA and one-way ANOVA were used for repeated measures. Intraclass correlation coefficients (ICCs) were drafted inter- and intra-raters for both methods and Pearson correlation (r) compared the two instruments. For values ranging from 1.0 to 0.81 , the reliability was considered excellent; from 0.80 to 0.61 , very good; from 0.60 to 0.41 , good; from 0.40 to 0.21 , reasonable; and, from 0.20 to 0.00 , poor ${ }^{16}$.

\section{RESULTS}

Participants consisted of 40 volunteers ( 8 men and 32 women) with mean age of $21.8 \pm 4.2$ years. Mean weight was $59.1 \pm 8.8 \mathrm{~kg}$, mean height was $1.66 \pm 0.08$ $\mathrm{m}$, and mean BMI was $21.3 \pm 1.9 \mathrm{~kg} / \mathrm{m}^{2}$.

Table 1 shows the inter-rater ICC for flexion and abduction. Using UG, ICC was excellent for both movements. Using CP, ICC was very good for flexion and very good for abduction. Intra-rater ICC was excellent for flexion and abduction using UG, and very good using $\mathrm{CP}$ (Table 2).

Table 1. Inter-rater correlation of ROM measurement of hip flexion and abduction

\begin{tabular}{|c|c|c|c|c|}
\hline \multirow{2}{*}{ Movement } & \multirow{2}{*}{ Instruments } & Rater 1 & Rater 2 & \multirow{2}{*}{ ICC } \\
\hline & & Mean (SD) & Mean (SD) & \\
\hline \multirow{2}{*}{$\begin{array}{l}\text { Flexion } \\
\text { (degrees) }\end{array}$} & UG & $122.1(8.5)$ & $122.7(7.8)$ & 0.92 \\
\hline & $C P$ & 119.1 (9.3) & $122.0(8.4)$ & 0.77 \\
\hline \multirow{2}{*}{$\begin{array}{l}\text { Abduction } \\
\text { (degrees) }\end{array}$} & UG & $19.4(4.4)$ & $20.1(5.7)$ & 0.91 \\
\hline & $C P$ & $21.4(5.2)$ & $20.6(6.3)$ & 0.80 \\
\hline
\end{tabular}

Table 2. Intra-rater correlation of ROM measurement of hip flexion and abduction

\begin{tabular}{|lcccc} 
& & Assessment 1 & $\begin{array}{c}\text { Assessment } \\
\text { Movement }\end{array}$ & \\
\cline { 3 - 4 } & Instruments & ICC \\
\cline { 3 - 4 } & & Mean (SD) & Mean (SD) & \\
\hline Flexion & UG & $122.7(7.8)$ & $121.9(7.1)$ & 0.95 \\
(degrees) & CP & $122.0(8.4)$ & $120.4(7.7)$ & 0.81 \\
\hline $\begin{array}{l}\text { Abduction } \\
\text { (degrees) }\end{array}$ & UG & $19.4(4.4)$ & $20.2(4.6)$ & 0.92 \\
*ICC (3.1): UG: goniometer: CP. photogrammetry & $21.4(5.2)$ & $22.4(4.1)$ & 0.89 \\
\hline
\end{tabular}

Table 3. Correlation between both instruments

\begin{tabular}{|lccc|}
\hline \multirow{2}{*}{ Movement } & UG Mean (SD) & CP Mean (SD) & \multirow{2}{*}{$\mathbf{r}^{*}$} \\
\cline { 2 - 3 } & Mean (SD) & Mean (SD) & \\
\hline Flexion & $122.1(8.5)$ & $119.1(9.3)$ & 0.92 \\
\hline Abduction & $19.4(4.4)$ & $21.4(5.3)$ & 0.82 \\
\hline
\end{tabular}

* Pearson correlation coefficient

UG: goniometer; CP: photogrammetry

Table 3 and Figure 3 present the correlation between UG and CP for hip flexion and abduction. For flexion, correlation was excellent, and for abduction, very good. 

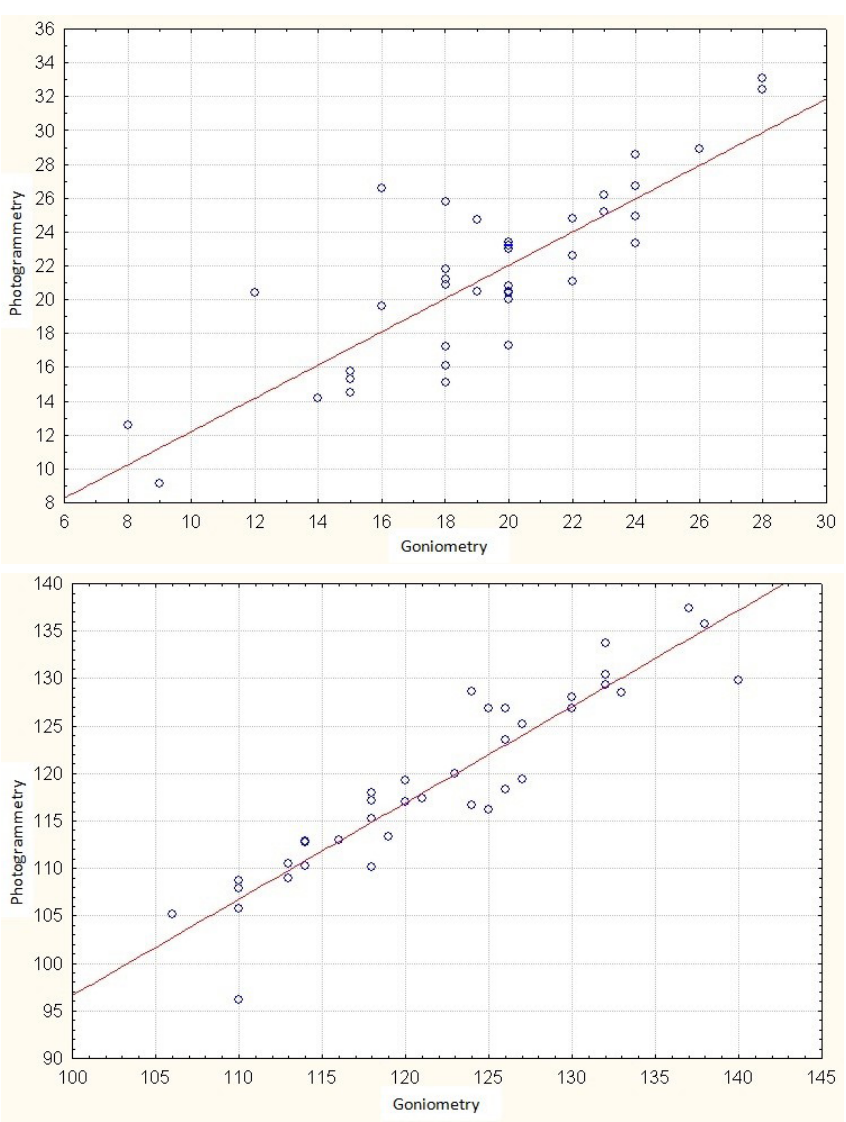

Figure 3. Correlation between instruments: Goniometry and Photogrammetry for hip abduction (A) and flexion (B)

\section{DISCUSSION}

Our study demonstrated very good inter- and intra-rater reliability on range of motion of flexion and abduction of the hip using UG and CP. Correlation between instruments is very good for flexion and abduction.

We tested inter- and intra-rater reliability of UG and CP for measuring ROM of hip flexion and abduction. We found that both methods are reproducible and highly correlated for the measured movements. Our findings are supported by previous results using $\mathrm{UG}^{1,2,6}$.

Photogrammetry is a reliable method for postural analysis and has been increasingly used to obtain specific measures of joint angles ${ }^{17}$. There are reliability studies on goniometry and photogrammetry for joints, such as the shoulder and cervical spine in sagittal view $^{18}$, and for hands, comparing flexion of the thumb and abduction of the fingers of the hands ${ }^{19}$.

Few studies compared the two methods for quantifying $\mathrm{ROM}^{17,18,19}$; the comparison of universal goniometer with inclinometer and visual estimation showed lower levels of correlation for abduction at standard position. Studies of range of hip abduction with patients in orthostatism are not available. We chose to measure patients in this position due to the difficulties in positioning the camera in other situations, as well as in reproducing what may happen in clinical practice. Because it is unusual to measure hip abduction on orthostatism, we expected to find a lower correlation than we did. It is possible that the good reliability was a function of careful training, pilot study, use of standard procedures, identification of reference points, and standard use of the zoom function in the software. Carregaro et al. ${ }^{20}$ used CP for the measurement of the hip angle during the "middle finger to the floor" test, finding high levels of inter- and intra-rater reliability, as well as good correlation with other flexibility tests, although validation was not performed.

Mean values for error are within 5 degrees, and therefore very good for use in clinical context ${ }^{21}$. Inter- and intra-rater reliability were similar, which is different from what was found by Rothstein ${ }^{7}$, where inter-rater agreement was lower than intrarater values, something often reported in the literature. It is possible that standardized training and methods contributed to reduce the differences, addressing limitations seen by others using imaging techniques ${ }^{15,22}$. Ferreira et al. ${ }^{15}$ highlight that, although the used software (PAS/SAPO) is easy to use, lack of training and past experience may affect $\mathrm{CP}$ results. We found a high correlation between UG and CP (highest for flexion), suggesting that the use of a standard posture and positioning helped the measurements by the raters.

Sources of variability of measurements using CP during hip flexion may have been partially driven by the reference axis that projected from the last rib, since this did not correct compensations of the spinal axis during movement. Theoretically, this may have altered the reference of the anatomical point, especially in abduction, because it was actively conducted and from bipedalism. Limitations of our study include the characteristics of the sample (healthy, with ROM and BMI within normal limits), which may not be generalizable. In fact, true patients may have pain, reduced ROM, and other limitations that might intervene in the measurements. Harrison ${ }^{23}$, however, found that the method can also be used in patients with pain. 
Because the two methods are reproducible and highly correlated, raters have options and may select one based on previous experience, costs, availability of equipment, time for conducting the tests, circumstances, and adequate environment. $\mathrm{CP}$ offers the advantage of electronically filing the data, therefore facilitating clinical follow-up. However, it is a method that is highly dependent on the standardized and meticulous positioning of the camera, requiring larger rooms for the equipment.

\section{STUDY LIMITATIONS}

The assessment was performed only with the asymptomatic population. Other studies should research methods for patients with dysfunctions.

\section{PRACTICAL APPLICATIONS}

The assessment of the range of motion of hip flexion and abduction is often performed in clinical practice. The reliability study on goniometry and photogrammetry offers scientific evidence in such a way that physical therapists can choose which method of evaluation is appropriate the most to their work dynamics and patient dysfunction. Photogrammetry has been increasingly used in physical therapy, and reliability studies are needed for other features of this method to be explored.

\section{CONCLUSION}

Inter- and intra-rater reliability is high when measuring range of motion of flexion and abduction of the hip using both UG and CP. Correlation between instruments is excellent for flexion and very good for abduction and both are valid. Future investigations might seek a more diversified sample and symptomatic patients.

\section{ACKNOWLEDGMENT OF FINANCIAL SUPPORT}

FAPESP - Fundação de Amparo à Pesquisa do Estado de São Paulo

\section{REFERENCES}

1. Batista LH, Camargo PR, Aiello GV, Oishi J, Salvini TF. Avaliação da amplitude articular do joelho: correlação entre as medidas realizadas com o goniômetro universal e no dinamômetro isocinético. Rev Bras Fisioter. 2006;10(2):1938. doi: 10.1590/S1413-35552006000200009.

2. Gajdosik RL, Bohannon RW. Clinical measurement of range of motion: review of goniometry emphasizing reliability and validity. Phys Ther. 1987;67(12):1867-72.

3. Conte AL, Marques AP, Casarotto RA, Amado-João SM. Handedness influences passive shoulder range of motion in nonathlete adult women. J Manipulative Physiol Ther. 2009;32(2):149-53. doi: 10.1016/j.jmpt.2008.12.006.

4. Sabari JS, Maltzev I, Lubarsky D, Liszkay E, Homel P. Goniometric assessment of shoulder range of motion: comparison of testing in supine and sitting positions. Arch Phys Med Rehabil. 1998;79(6):647-51. doi: 10.1016/ S0003-9993(98)90038-7.

5. Venturini C, Ituassú NT, Teixeira LM, Deus CVO. Confiabilidade intra e interexaminadores de dois métodos de medida da amplitude ativa de dorsiflexão do tornozelo em indivíduos saudáveis. Rev Bras Fisioter. 2006;10(4):407-11. doi: 10.1590/ S1413-35552006000400008.

6. Gogia PP, Braatz JH, Rose SJ, Norton BJ. Reliability and validity of goniometric measurements at the knee. Phys Ther. 1987;67(2):192-5.

7. Rothstein JM, Miller PJ, Roettger RF. Goniometric Reliability in a clinical setting: elbow and knee measurementes. Phys Ther. 1983;63(10):1611-5.

8. Döhnert MB, Tomasi E. Validade da fotogrametria computadorizada na detecção de escoliose idiopática adolescente. Rev Bras Fisioter. 2008;12(4):290-7. doi: 10.1590/S1413-35552008000400007.

9. Iunes DH, Castro FA, Salgado HS, Moura IC, Oliveira AS, Bevilaqua-Grossi D. Confiabilidade intra e interexaminadores e repetibilidade da avaliação postural pela fotogrametria. Rev Bras Fisioter. 2005;9(3):327-34.

10. Sacco ICN, Alibert S, Queiroz BWC, Pripas D, Kieling I, Kimura AA, et al. Confiabilidade da fotogrametria em relação a goniometria para avaliação postural de membros inferiores. Rev Bras Fisioter. 2007:11(5):411-7. doi: 10.1590/ S1413-35552007000500013.

11. American Society for Photogrammetry and Remote Sensing. What is ASPRS? [Internet]. Bethesda: American Society for Photogrammetry and Remote Sensing; 2000. [Accessed on: July 25, 2012]. Available from: http://www.asprs.org/AboutUs/What-is-ASPRS.html

12. Sato TO, Vieira ER, Gil Coury HJC. Análise da confiabilidade de técnicas fotométricas para medir a flexão anterior do tronco. Rev Bras Fisiot. 2003;7(1):53-99.

13. Matsudo SM, Matsudo VR, Araújo T, Andrade D, Andrade E, Oliveira L, et al. Nível de atividade física da população do Estado de São Paulo: análise de acordo com o gênero, idade, nível socioeconômico, distribuição geográfica e de conhecimento. Rev Bras Ciên e Mov. 2002;10(4):41-50. 
14. Marques AP. Manual de goniometria. $2^{\underline{a}}$ ed. Barueri: Manole; 2014.

15. Ferreira EAG, Duarte M, Maldonado EP, Burke TN, Marques AP. Postural assessment software (PAS/SAPO): validation and reliability. Clinics. 2010;65(7):675-81. doi: 10.1590/ S1807-59322010000700005.

16. Bland JM, Altman DG. Comparing methods of measurement: why plotting difference against standard method is misleading.Lancet 1995;346:1085-7.

17. Singla D, Vegar Z. Methods of postural assessment used for sports persons. Jounal of Clinical and Diagnostic Research. 2014; 8(4): 01-04.

18. Ruivo RM, Pezarat-Correia P, Carita Al. Intrarater and interrater reliability of photographic measurement of upperbody standing posture of adolescents. Jounal of Manipulative and Physiological Therapeutics. 2015; 38: 74-80.

19. Carvalho RMF, Mazzer N, Barbieri $\mathrm{CH}$. Analysis of the reliability and reproducibility of goniometry compared to hand photogrammetry. Acta Ortop Bras. 2012; 20 (3): 139-49.

20. Holm I, Bolstad B, Lütken T, Ervik A, Røkkum M, Steen H. Reliability of goniometric measurements and visual estimates of hip ROM in patients with osteoarthrosis. Physiother Res Int 2000;5:241-8.
21. Clapper MP, Wolf SL. Comparison of the reliability of the Orthoranger and the standard goniometer for assessing active lower extremity range of motion. Phys Ther 1988;68:214-8.

22. Clapis PA, Davis SM, Davis RO. Reliability of inclinometer and goniometric measurements of hip extension flexibility using the modified Thomas test. Physiother Theory Pract 2008:24:135-41.

23. Carregaro RL, Silva LCCB, Gil-Coury HJC. Comparação entre dois testes clínicos para avaliar a flexibilidade dos músculos posteriores da coxa. Rev Bras Fisioter 2007;11: 139-45.

24. Piriyaprasarth P, Morris ME, Winter A, Bialocerkowski $A E$. The reliability of knee joint position testing using electrogoniometry. BMC Musculoskelet Disord 2008;22: 9-6.

25. Normand MC, Descarreaux M, Harrison DD, Harrison DE, Perron DL, Ferrantelli JR, Janik TJ. Three dimensional evaluation of posture in standing with the PosturePrint: an intra- and inter-examiner reliability study. Chiropr Osteopat 2007;15:15.

26. Harrison DE, Harrison DD, Colloca CJ, Betz J, Janik TJ, Holland B. Repeatability over time of posture, radiograph positioning, and radiograph line drawing: an analysis of six control groups. J Manipulative Physiol Ther 2003;26:87-98. 